\title{
Bufadienolides と数種の強心薬のモルモット心臓に対する作用
}

\author{
平井 康晴*, 森下 信一*, 伊藤 千尋*, 坂梨 又郎** \\ 救心製薬 (株) 総合研究所*, 琉球大学医学部医学科薬理学教室 ${ }^{* *}$ \\ (1992年 4 月15日)
}

\begin{abstract}
要約：センソに含有される bufalin (BF) や cinobufagin (CB) などの bufadienolides の心室筋 $\mathrm{Na}^{+}, \mathrm{K}^{+}$-ATPase 活性とモルモットの乳頭筋活動電位に対する作用および開胸モルモットを用いた in vivo での強心作用を数種の強心莱と比較した. 1) モルモットの心室筋 $\mathrm{Na}^{+}, \mathrm{K}^{+}$-ATPase 活性阻害作 用強度はBF>digoxin (DG) >digitoxin (DT) > telocinobufagin $>$ gamabufotalin $>$ cinobufotalin $>$ CB $>$ g-strophanthin (GS) $>$ digitoxigenin (DTG) $>$ resibufogenin (RB) の順

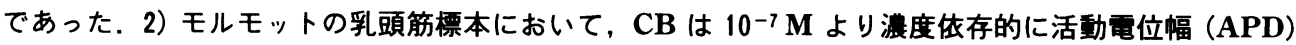
を短縮した．APD 短縮作用の強さは GS $>$ CB $>$ DTG $>$ DT の順であった． 3） GS, CB, DT および DG の $0.1 \sim 0.4 \mathrm{mg} / \mathrm{kg}$ 静脈内投与により強心作用が認められた. 4) 十二指腸内投与後の強心作用強度 は methyldigoxin, proscillaridin $>$ BF $>$ CB $>$ DG $>$ センソ $>$ DT, DTG, RB の順であった.
\end{abstract}

\section{緒言}

センソは古くから強心薬として伝統薬に配合されてい る生薬である. bufalin (BF) や cinobufagin (CB) はセ ンソに含まれる bufadienolides であるが，我々はモル モットの摘出心房標本に拈いて, CB が digitoxin (DT) と同等以上の強心作用を有することを認めている1). CB および他の bufadienolides の強心作用についてはモ ルモット灌流心葴を用いた研究2)をはじめとして多くの 報告がなされている3). 今回，我々はモルモット心室筋 $\mathrm{Na}^{+}, \mathrm{K}^{+}$-ATPase 活性，モルモット心室乳頭筋活動電 位および生体位モルモット心臓に対する $\mathrm{BF}$ と $\mathrm{CB}$ の 作用を数種の強心薬と比較することにより， $\mathrm{BF}$ と $\mathrm{CB}$ の強心作用発現に拈ける薬理学的特性を詳細に検討した ので報告する．

\section{実 験 方 法}

\section{1. 実験動物}

Hartley 系雄性モルモットを静岡県実験動物農業協同 組合あるいは金丸実験動物店より入手し，少なくとも6 日間の予備飼育後, 実験に供した。

*干166 東京都杉並区和田1-31-7

**\%903-01 沖縄県中頭郡西原町字上原 207

\section{2. 使用薬物}

センソは日本薬局方品を, $\mathrm{CB}, \mathrm{BF}$, telocinobufagin (TCB), gamabufotalin (GBF), cinobufotalin (CBF) お よび resibufogenin (RB) は小松と岡野4) の方法に準拠 してシリカゲルカラムクロマトグラフィーにてセンソよ り単離したものを使用した. 今回実験に使用したこれら bufadienolides の化学構造を図 1 に示した. 対照薬とし $\tau \mathrm{DT}$ (和光純薬), digitoxigenin (DTG, 東京化成), digoxin (DG, シグマ社), methyldigoxin (MDG, 山之 内), proscillaridin (PC, 大日本), aminophylline (APY, シグマ社) および g-strophanthin (GS, 東京化成)を使 用した。

3. 心室筋 $\mathrm{Na}^{+}, \mathrm{K}^{+}-\mathrm{ATPase}$ 活性に対する作用 モルモット（体重 550～720 g) を断頭, 放血致死後, 左心室筋を切り出して Kim ら ${ }^{5)}$ の方法を参考に以下の よらに行なった. $10 \mathrm{mM}$ Tris- $\mathrm{HCl}$ 緩衝液 $(\mathrm{pH} \mathrm{7.5)}$ 拈 よび 2 mM EDTAを加え, 心筋ホモジネートを作製し た.心筋ホモジネート $0.1 \mathrm{ml}$ に $0.1 \mathrm{M}$ Tris- $\mathrm{HCl}$ 緩衝 液 (pH 7.5) $0.5 \mathrm{ml}, 1 \mathrm{M} \mathrm{NaCl} \cdot 50 \mathrm{mM} \mathrm{MgCl}_{2} \cdot 150$ $\mathrm{mM} \mathrm{KCl} \cdot 50 \mathrm{mM} \mathrm{NaN}_{3} 0.1 \mathrm{ml}$ および蒸留水 $0.1 \mathrm{ml}$ 混和し, さらに被験薬液 $0.1 \mathrm{ml}$ を加え, $37^{\circ} \mathrm{C}, 5$ 分間の 予備加温後, $50 \mathrm{mM}$ Tris-ATP 溶液 $0.1 \mathrm{ml}$ を加之て 37 ${ }^{\circ} \mathrm{C}, 30$ 分間のインキュベーションを行なった $\left(\operatorname{Kim} 5^{5)}\right.$ は 10分間のインキュベーション時間で実験を行なっている 

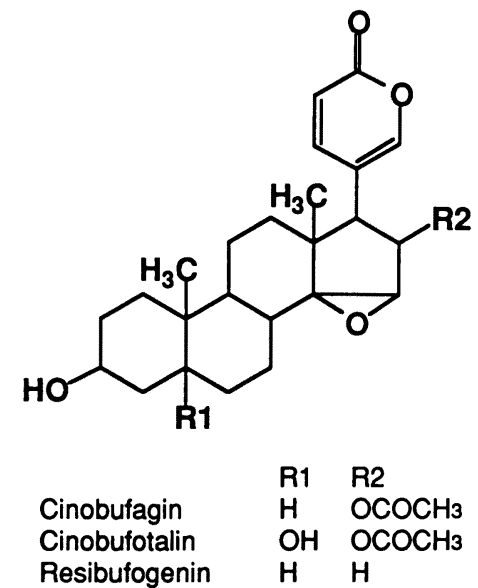
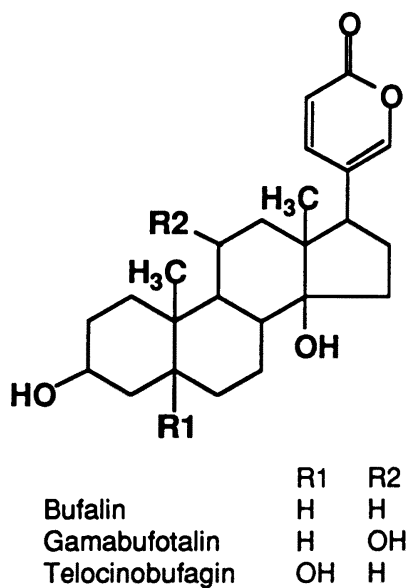

Fig 1 Chemical structures of bufadienolides used in this study.

が，測定精度を向上させるため，30分間のインキュ ベーション時間とした).インキュベーション終了後, $10 \%$ リクロロ酢酸溶液 $1 \mathrm{ml}$ を加え, 室温で $3000 \mathrm{rpm}$, 15分間の遠心分離を行ない, 上清を得た. $1 \%$ モリブデ ン酸アンモニウムの $1.15 \mathrm{~N} \mathrm{H}_{2} \mathrm{SO}_{4}$ 溶液に $\mathrm{FeSO}_{4}$ ・ $7 \mathrm{H}_{2} \mathrm{O}$ が $4 \%$ となるよらに用時溶解した液 $4.0 \mathrm{ml}$ を上 清 $0.5 \mathrm{ml}$ に添加し, その10分後に $700 \mathrm{~nm}$ に扣いて吸 光度を測定し, 総 ATPase 活性を求めた. $\mathrm{Mg}^{2+}$-ATPase 活性は蒸留水 $0.1 \mathrm{ml}$ の代わりに $1 \mathrm{mM} \mathrm{GS} 0.1 \mathrm{ml}$ を加えて同様に測定することにより求めた. $\mathrm{Na}^{+}, \mathrm{K}^{+}$. ATPase 活性は総 ATPase 活性から $\mathrm{Mg}^{2+}$-ATPase 活 性を差し引くことにより算出した．ホモジネート中のタ ンパク質量は Lowry ら6) の方法を用いて定量した。1 群につき 5 匹のモルモットを使用した．被験薬はプロピ レングリコールに溶解後, 蒸留水で希釈 (最終プロピレ ングリコール濃度 $3 \%$ ）して添加した。なお，各被験薬 の $\mathrm{Na}^{+}, \mathrm{K}^{+}$-ATPase 活性阻害率 (\%) は盲検 ( $3 \%$ プロ ピレングリコール) と被験薬の吸光度差を盲検と 0.1 $\mathrm{mM} \mathrm{GS}$ 存在下の吸光度差で除した值を 100 倍すること により求めた.

\section{4. 乳頭筋活動電位に対する作用}

モルモット（体重 $230 \sim 680 \mathrm{~g}$ ）を断頭, 放血致死後速 やかに心蔵を摘出し, 乳頭筋を切り出し, $95 \% \mathrm{O}_{2}-5$ $\% \mathrm{CO}_{2}$ の混合ガスを通気した Tyrode 液（組成 $(\mathrm{mM})$ : $\mathrm{NaCl} 137, \mathrm{KCl} 2.7, \mathrm{CaCl}_{2}$ 1.8, $\mathrm{MgCl}_{2} 1.1, \mathrm{NaH}_{2} \mathrm{PO}_{4} 0.4$, $\mathrm{NaHCO}_{3} 12$, グルコース 5.6 , 液温 : $\left.36.5 \pm 0.5^{\circ} \mathrm{C}\right)$ で 保生した標本を電気刺激装置 (ME2100-101, ME コ マーシャル)により頻度 $1.0 \mathrm{~Hz}$, 持続時間 $5 \mathrm{msec}$ の矩 形波で刺激し, 活動電位を誘発した。活動電位の記録は
$3 \mathrm{M} \mathrm{KCl}$ を満たした微小ガラス電極を介して微小電極 増幅器 (MZ-4, 日本光電) を用いて行なった. 細胞にガ ラス電極を刺入した状態で持続的に活動電位を誘発し, 被験薬添加前と添加10および30分後の同一細胞における 静止膜電位 (RMP), 活動電位高 (APA), 活動電位幅 $(50 \%$ 再分極時, APD 50$)$, 活動電位最大立ち上がり速

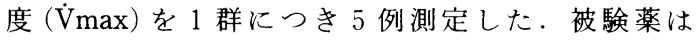
Tyrode 液に溶解あるいは懸濁して, 灌流液中に添加し た。

\section{5. 開胸モルモットにおける強心作用}

ウレタン $(1.5 \mathrm{~g} / \mathrm{kg}$, i.p.) により麻酔したモルモット （体重 210４10 g）を背位に固定し，小動物用人工呼吸 器 (SN-480-7, シナノ製作所) を用いて人工呼吸下に, 第 6 肋間にて切開後, 切開部より胸骨の両側を鎖骨まで 切開し, 左右に胸骨を拡げて心葴を露出した。 心尖部に 系を通して等尺性張力ピックアップ (TB-611T, 日本光 電)につなぎ，ひずみ圧力用アンプ (AP-621G， 日本光 電)により心収縮力を, また心収縮力より瞬時心拍計二 ニット (AT-601G, 日本光電) を介して心拍数をサーマ ルアレイレコーダ $(\mathrm{WS}-681 \mathrm{G}$, 日本光電) に記録した. 実験中は動物保温装置 (KN-474, 夏目製作所)により, 体温を $37^{\circ} \mathrm{C}$ に保った。 心収縮曲線に呼吸などの動きが 混入しないよらにするため, 横隔神経を切断して横隔膜 の運動を止め, 生理食塩水を浸したガーゼにより肺と心 蔵が直接触れないよらにした。被験薬は十二指腸内投与 の場合, 蒸留水に懸濁あるいは溶解し, 十二指腸内に挿 入したカニューレを介して投与した．静脈内投与の場合 は, 被験薬をプロピレングリコールに溶解後, 生理食塩 水で希釈（最終プロピレングリコール濃度 $20 \%$ ）して体 
Table 1 Effects of bufadienolides and cardenolides on $\mathrm{Na}^{+}, \mathrm{K}^{+}$-ATPase activity in the homogenate of guinea pig ventricular muscle

\begin{tabular}{|c|c|c|}
\hline Drugs & $\begin{array}{c}\mathrm{IC} 50 \\
\left(\times 10^{-8} \mathrm{M}\right)\end{array}$ & $95 \%$ Confidence limits \\
\hline Bufalin & 4.7 & $0.5 \sim 23.7$ \\
\hline Cinobufagin & 53.6 & $25.6 \sim 120$ \\
\hline Resibufogenin & 453 & $382 \sim 911$ \\
\hline Telocinobufagin & 16.5 & $16.0 \sim 31.2$ \\
\hline Cinobufotalin & 48.5 & $27.5 \sim 85.9$ \\
\hline Gamabufotalin & 37.9 & $21.5 \sim 58.9$ \\
\hline Digoxin & 13.5 & $5.1 \sim 30.4$ \\
\hline Digitoxin & 14.7 & $7.0 \sim 27.4$ \\
\hline Digitoxigenin & 225 & $161 \sim 328$ \\
\hline g-Strophanthin & 70.9 & $37.8 \sim 158$ \\
\hline
\end{tabular}

重 $1 \mathrm{~kg}$ あたり $2 \mathrm{ml}$ を頸静脈より投与した。 1 群につ き 5 匹のモルモットを使用し，被験薬投与 $10,20,30,60$, $90 お よ ひ ゙ 120$ 分後における心収縮力と心拍数の変化を記 録した。

実験結果は $\mathrm{F}$ 検定の後 Student あるいは Welch のttestによって解析した，分散が異なる場合は後者を用い た.これらはすべて両側検定とした.

\section{実 験 結 果}

\section{1. 心室筋 $\mathrm{Na}^{+}, \mathrm{K}^{+}-\mathrm{ATPase}$ 活性に対する作用}

本実験に打ける薬物非添加時の $\mathrm{Na}^{+}, \mathrm{K}^{+}$-ATPase 活 性および $\mathrm{Mg}^{2+}$-ATPase 活性は平均值でそれぞれ 0.75 $\mu \mathrm{mol} \mathrm{Pi} / \mathrm{mg}$ protein/ $30 \mathrm{~min}$ および $1.77 \mu \mathrm{mol} \mathrm{Pi} / \mathrm{mg}$ protein/30 min であった. 被験薬存在下の $\mathrm{Mg}^{2+}$-ATPase 活性は $1.48 \sim 2.11 \mu \mathrm{mol} \mathrm{Pi} / \mathrm{mg}$ protein $/ 30 \mathrm{~min}$ であり, 有意な変化は認められなかった。一方, $\mathrm{Na}^{+}, \mathrm{K}^{+}$ATPase 活性に対しては今回検討した被験薬は濃度依 存的に $\mathrm{Na}^{+}, \mathrm{K}^{+}$-ATPase 活性を阻害した。 BF や CB などの bufadienolides 扣よび数種の強心薬の $\mathrm{Na}^{+}, \mathrm{K}^{+}$. ATPase 活性に対する作用を図 2 に示した。 $50 \%$ 阻害 濃度（IC50）を比較したところ（表 1), BF の IC50 が最 も低く $4.7 \times 10^{-8} \mathrm{M}, \mathrm{RB}$ のIC50 は最も高く $4.5 \times 10^{-6}$ $\mathrm{M}$ であった。被験薬の $\mathrm{Na}^{+}, \mathrm{K}^{+}$-ATPase 活性阻害強度 は $\mathrm{BF}>\mathrm{DG}>\mathrm{DT}>\mathrm{TCB}>\mathrm{GBF}>\mathrm{CBF}>\mathrm{CB}>\mathrm{GS}>\mathrm{DTG}$ $>\mathrm{RB}$ の順であった.

\section{2. 乳頭筋活動位に対する作用}

$\mathrm{CB}$ 添加液の調製限界である $1 \times 10^{-6} \mathrm{M}$ を最高濃度 として乳頭筋活動電位に対する作用を検討した。 CB は $3 \times 10^{-7} \mathrm{M}$ より $1 \times 10^{-6} \mathrm{M}$ で濃度依存的に APD50を 短縮させたが, $1 \times 10^{-6} \mathrm{M}$ の濃度でも RMP, APA 扣よ

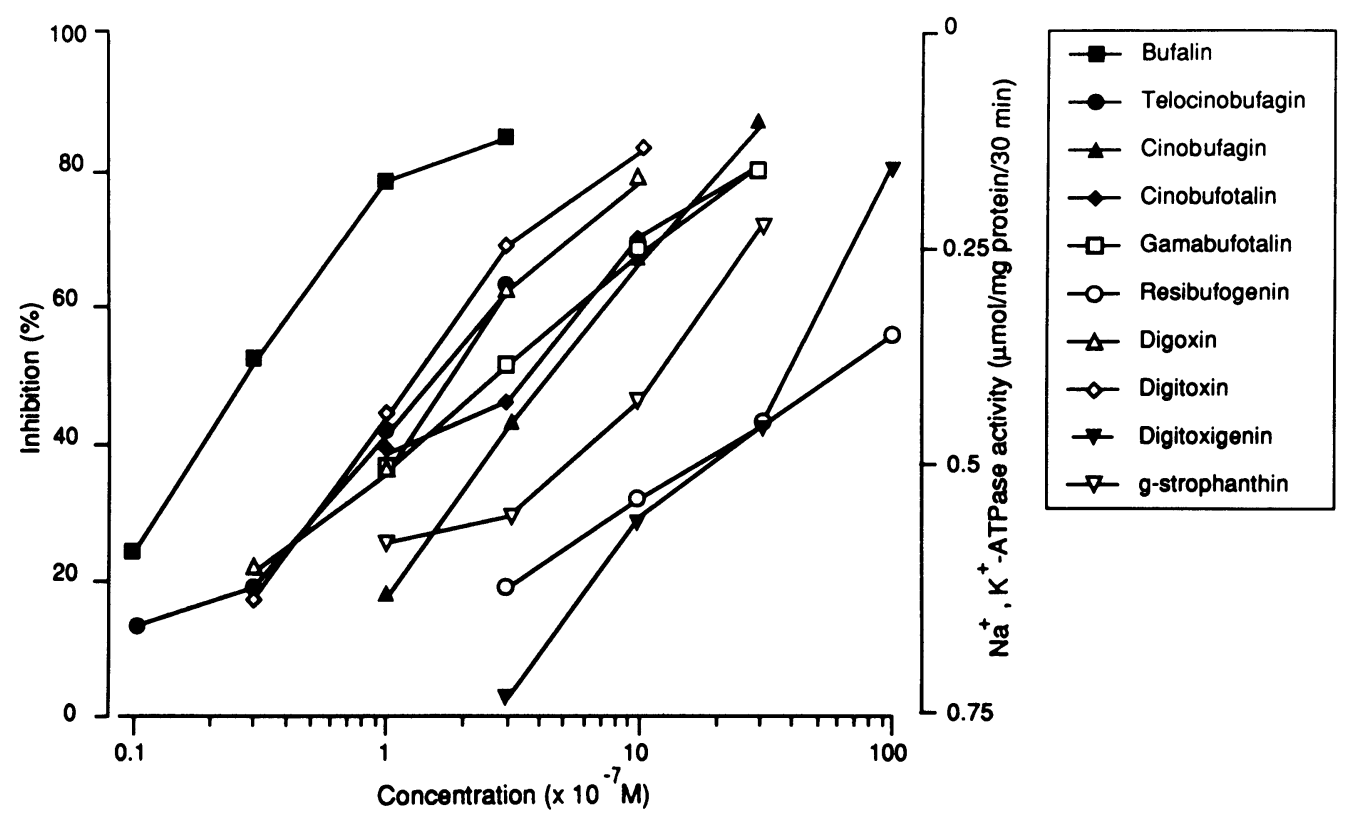

Fig 2 Effects of bufadienolides and cardenolides on $\mathrm{Na}^{+}, \mathrm{K}^{+}$-ATPase activities in the homogenate of ventricular muscle of guinea pigs. Plots are expressed as the mean of 5 animals. 
Table 2 Effects of cinobufagin and other cardiotonics on the action potential in guinea pig papillary muscle cells

\begin{tabular}{lccccc}
\hline Drugs & $\begin{array}{c}\text { Concentration } \\
\left(\times 10^{-8} \mathrm{M}\right)\end{array}$ & $\begin{array}{c}\mathrm{RMP} \\
(\mathrm{mV})\end{array}$ & $\begin{array}{c}\text { APA } \\
(\mathrm{mV})\end{array}$ & $\begin{array}{c}\text { APD50 } \\
(\mathrm{msec})\end{array}$ & $\begin{array}{c}\text { Vmax } \\
(\mathrm{V} / \mathrm{sec})\end{array}$ \\
\hline Control & & $-92.0 \pm 2.1$ & $130.4 \pm 0.7$ & $131.4 \pm 5.3$ & $158.2 \pm 5.6$ \\
Cinobufagin & 1 & $-91.2 \pm 2.3$ & $130.8 \pm 2.5$ & $113.6 \pm 7.3$ & $148.0 \pm 3.7$ \\
& 3 & $-90.8 \pm 3.6$ & $129.6 \pm 4.3$ & $119.0 \pm 12.4$ & $147.4 \pm 6.8$ \\
& 10 & $-89.2 \pm 1.0$ & $128.8 \pm 1.4$ & $120.0 \pm 10.6$ & $147.2 \pm 4.2$ \\
& 30 & $-94.0 \pm 3.6$ & $124.8 \pm 3.4$ & $85.4 \pm 9.0^{* *}$ & $151.0 \pm 2.8$ \\
Digitoxin & 100 & $-88.4 \pm 3.8$ & $123.6 \pm 4.4$ & $74.0 \pm 3.8^{* *}$ & $148.2 \pm 5.9$ \\
Digitoxigenin & 100 & $-93.2 \pm 2.2$ & $130.4 \pm 1.7$ & $132.6 \pm 6.6$ & $156.0 \pm 4.3$ \\
g-Strophanthin & 100 & $-90.8 \pm 2.2$ & $123.6 \pm 2.5$ & $93.6 \pm 4.5^{* *}$ & $144.4 \pm 6.4$ \\
& 1 & $-95.2 \pm 3.3$ & $129.6 \pm 2.3$ & $128.4 \pm 11.0$ & $145.0 \pm 4.1$ \\
& 3 & $-93.0 \pm 2.4$ & $129.2 \pm 1.4$ & $104.6 \pm 5.2^{* *}$ & $144.6 \pm 2.7$ \\
& 10 & $-90.8 \pm 5.0$ & $115.2 \pm 7.4$ & $38.6 \pm 12.9^{* *}$ & $139.2 \pm 5.6^{*}$ \\
\hline
\end{tabular}

*: $\mathrm{P}<0.05,{ }^{* *}: \mathrm{P}<0.01$, as compared with the control group by the $t$-test. The data are measured $30 \mathrm{~min}$ after administration of drugs and expressed as the mean $\pm \mathrm{S}$.E. (Number of preparations $=5$ ). RMP: resting membrane potential, APA: action potential amplitude, APD50: action potential duration to $50 \%$ repolarization.

び V $\max$ には影響を与えなかった（表 2，図 3 ）。GS は $3 \times 10^{-8} \mathrm{M}$ の濃度より APD50 を短縮させ, $1 \times 10^{-7}$ $\mathrm{M}$ の濃度では $\dot{\mathrm{V}} \max$ も減少させた. $\mathrm{CB}$ は $1 \times 10^{-7} \mathrm{M}$ の濃度で APD50 を有意に短縮させなかったことから， その APD50 短縮作用は GSより弱いことがわかった
(表 2 ). DTG は $1 \times 10^{-6} \mathrm{M}$ の濃度において APD50を 短縮させたがその程度は同濃度の $\mathrm{CB}$ の作用より弱 かった（表 2). DTは $1 \times 10^{-6} \mathrm{M}$ の濃度においても APD50 に影響を与えなかったことから，その APD50 短縮作用はもしあったとしても DTGより弱いことが示

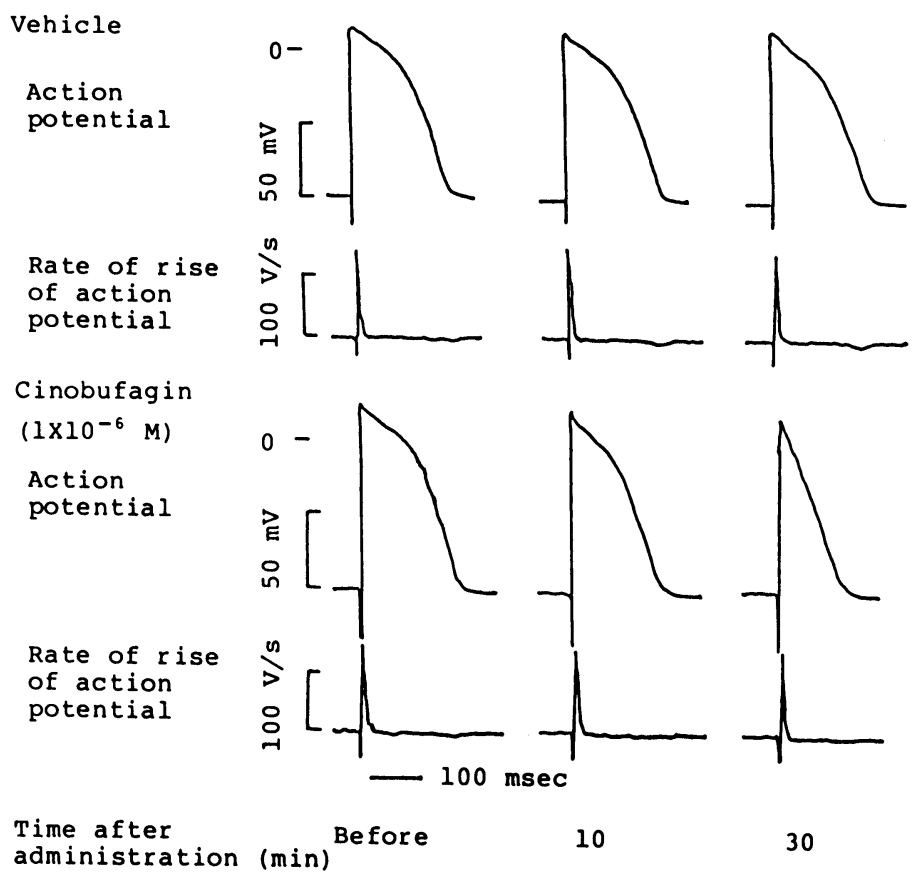

Fig 3 Effect of cinobufagin on the action potential and the rate of action potential rise of the guinea pig papillary muscle cell. 
Table 3 Effects of intravenous administration of cinobufagin and other cardiotonics on myocardial contractile force in guinea pigs

\begin{tabular}{|c|c|c|c|c|c|c|c|c|}
\hline \multirow{3}{*}{ Drugs } & \multirow{3}{*}{$\begin{array}{c}\text { Dose } \\
(\mathrm{mg} / \mathrm{kg})\end{array}$} & \multirow{3}{*}{$\begin{array}{c}\text { Before } \\
(\mathrm{g})\end{array}$} & \multicolumn{6}{|c|}{$\triangle$ Change $(\%)$} \\
\hline & & & \multicolumn{6}{|c|}{ Time after administration ( $\min )$} \\
\hline & & & 10 & 20 & 30 & 60 & 90 & 120 \\
\hline Control & & $5.62 \pm 0.41$ & $-0.2 \pm 0.2$ & $2.0 \pm 1.3$ & $0.6 \pm 1.2$ & $0.2 \pm 2.3$ & $1.9 \pm 3.0$ & $3.8 \pm 3.5$ \\
\hline Cinobufagin & 0.2 & $6.22 \pm 0.24$ & $20.1 \pm 4.4^{* *}$ & $14.2 \pm 5.4$ & $14.9 \pm 5.0^{*}$ & $13.4 \pm 3.6^{*}$ & $8.1 \pm 1.5$ & $4.9 \pm 1.9$ \\
\hline Digoxin & 0.4 & $5.81 \pm 0.11$ & $15.9 \pm 2.6^{* *}$ & $7.7 \pm 3.2$ & $9.0 \pm 2.4^{*}$ & $7.0 \pm 2.7$ & $5.0 \pm 1.8$ & $5.6 \pm 1.5$ \\
\hline Digitoxin & 0.4 & $5.68 \pm 0.20$ & $16.2 \pm 2.4^{* *}$ & $11.0 \pm 1.3^{* *}$ & $8.3 \pm 1.2^{* *}$ & $9.6 \pm 3.8$ & $8.9 \pm 5.7$ & $6.4 \pm 3.7$ \\
\hline g-Strophanthin & 0.1 & $5.76 \pm 0.12$ & $10.5 \pm 3.3^{* *}$ & $8.5 \pm 2.1^{*}$ & $8.5 \pm 1.6^{* *}$ & $8.2 \pm 1.5^{*}$ & $9.9 \pm 2.6$ & $11.0 \pm 3.3$ \\
\hline
\end{tabular}

The data are expressed as the mean \pm S.E. (Number of guinea pigs $=5$ ). ${ }^{*}: \mathrm{P}<0.05,{ }^{* *}: \mathrm{P}<0.01$, as compared with the control group by the $t$-test.

された（表 2 ）．GS が $1 \times 10^{-7} \mathrm{M}$ の濃度で $\mathrm{V} \max$ を有 意に抑制した以外，すべての被験薬は検討した濃度で RMP, APA および V $\max$ に影響を与えなかった（表 2 ）。

\section{3. 開胸モルモットにおける強心作用}

1）静脈内投与

$\mathrm{CB}, \mathrm{DG}, \mathrm{DT}, \mathrm{GS}$ の $0.1 \sim 0.4 \mathrm{mg} / \mathrm{kg}$ 投与により，投 与10分後においては投与前值に対し10～20\%の心収縮力 増加が認められ，いずれも有意な変化であった。また， この増加作用は投与後30〜60分まで持続していた（表 3 ）. 一方, 心拍数に対しては CB のみが軽度の増加作用を 示し，この作用は投与後 60 分まで持続した（表 4 ）。な 扣，GS では投与60分後に有意な徐脈を呈した（表 4 ）.

2）十二指腸内投与

静脈内投与の結果ならびにセンソ中の $\mathrm{CB}$ や $\mathrm{BF}$ の 含有量を参考にして投与量を決定した． CB（図 4)，
DG，センソ, BF, MDG, PC は, それぞれ 4, 4, 4, 1, 1, $0.5 \mathrm{mg} / \mathrm{kg}$ より心拍数に影響を与えずに有意に心収縮 力を増加させた（表 5,6). MDG と PC の心収縮力増 加作用を $1 \mathrm{mg} / \mathrm{kg}$ の用量で比較するとほぼ同等と考え られ，検討した被験薬中最も強力であった（表 5 ). BF の $1 \mathrm{mg} / \mathrm{kg}$ の用量に打ける心収縮力増加作用は, MDG や PC に比べ若干弱いながらも, BF がかなり強 力な作用を有していることが示された（表 5 ）。 4 $\mathrm{mg} / \mathrm{kg}$ より心収縮力増加作用を示した $\mathrm{CB}, \mathrm{DG}$ 扣よび センソの作用強度は $\mathrm{CB}>\mathrm{DG}>$ センソの順であり, $\mathrm{BF}$ よりは弱い作用であることが示された（表 5 ）。一方， RB，DT, DTG はそれぞれ $8,8,16 \mathrm{mg} / \mathrm{kg}$ まで投与した が，投与後 2 時間経過しても心収縮力および心拍数に明 らかな作用はみられず，作用はあったとしてもセンソよ りかなり弱いものと思われた（表 5 ). APYは 6.25
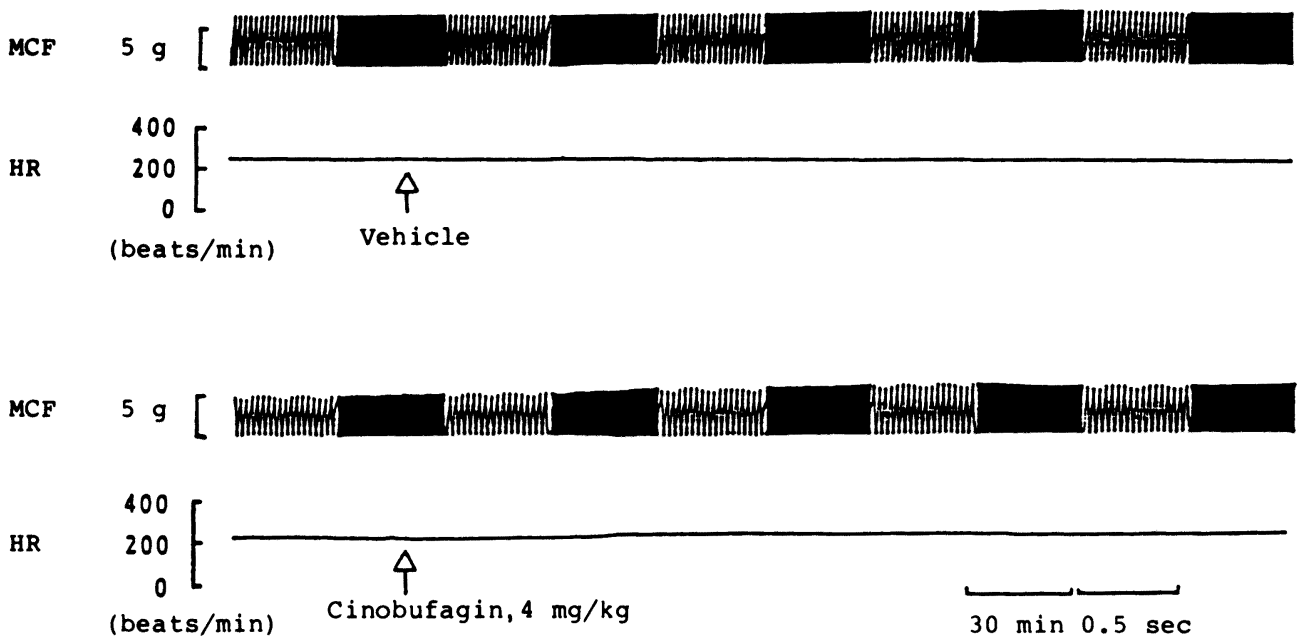

Fig 4 Effect of intraduodenal administration of cinobufagin on myocardial contractile force (MCF) and heart rate (HR) in guinea pig. 
Table 4 Effects of intravenous administration of cinobufagin and other cardiotonics on heart rate in guinea pigs

\begin{tabular}{|c|c|c|c|c|c|c|c|c|}
\hline \multirow{3}{*}{ Drugs } & \multirow{3}{*}{$\begin{array}{c}\text { Dose } \\
(\mathrm{mg} / \mathrm{kg})\end{array}$} & \multirow{3}{*}{$\begin{array}{c}\text { Before } \\
\text { beats/min }\end{array}$} & \multicolumn{6}{|c|}{$\triangle$ Change $(\%)$} \\
\hline & & & \multicolumn{6}{|c|}{ Time after administration (min) } \\
\hline & & & 10 & 20 & 30 & 60 & 90 & 120 \\
\hline Control & & $222 \pm 10$ & $4.5 \pm 2.4$ & $0.6 \pm 1.6$ & $-0.5 \pm 1.1$ & $-0.9 \pm 1.0$ & $-2.9 \pm 2.1$ & $-2.4 \pm 2.2$ \\
\hline Cinobufagin & 0.2 & $224 \pm 6$ & $9.9 \pm 2.9$ & $8.6 \pm 2.3^{*}$ & $7.4 \pm 2.3^{*}$ & $4.7 \pm 1.8^{*}$ & $1.9 \pm 0.7$ & $-1.1 \pm 0.6$ \\
\hline Digoxin & 0.4 & $218 \pm 7$ & $4.9 \pm 2.2$ & $3.5 \pm 2.0$ & $2.3 \pm 1.4$ & $2.3 \pm 2.4$ & $2.2 \pm 1.8$ & $2.3 \pm 2.0$ \\
\hline Digitoxin & 0.4 & $222 \pm 5$ & $2.5 \pm 1.6$ & $0.7 \pm 1.1$ & $-0.8 \pm 1.5$ & $-1.6 \pm 2.4$ & $-3.3 \pm 1.8$ & $-6.3 \pm 2.1$ \\
\hline g-Strophanthin & 0.1 & $219 \pm 10$ & $1.2 \pm 1.7$ & $-2.9 \pm 2.2$ & $-5.6 \pm 2.0$ & $-6.9 \pm 1.9^{*}$ & $-5.8 \pm 1.3$ & $-4.7 \pm 1.5$ \\
\hline
\end{tabular}

The data are expressed as the mean \pm S.E. (Number of guinea pigs $=5$ ). ${ }^{*}: P<0.05$, as compared with the control group by the $t$-test.

Table 5 Effects of intraduodenal administration of cinobufagin, bufalin, toad venom and other cardiotonics on myocardial contractile force in guinea pigs

\begin{tabular}{|c|c|c|c|c|c|c|c|c|c|}
\hline \multirow{3}{*}{ Drugs } & \multirow{3}{*}{$\begin{array}{l}\text { Dose } \\
\mathrm{ag} / \mathrm{kg} \text { ) }\end{array}$} & \multirow{3}{*}{$\mathrm{N}$} & \multirow{3}{*}{$\begin{array}{l}\text { Before } \\
\text { (g) }\end{array}$} & \multicolumn{6}{|c|}{$\triangle$ Change $(\%)$} \\
\hline & & & & \multicolumn{6}{|c|}{ Time after administration $(\mathrm{min})$} \\
\hline & & & & 10 & 20 & 30 & 60 & 90 & 120 \\
\hline Control & & 15 & $5.71 \pm 0.14$ & $0.0 \pm 0.6$ & $0.5 \pm 0.7$ & $0.2 \pm 0.7$ & $2.2 \pm 1.0$ & $3.8 \pm 1.0$ & $5.2 \pm 1.3$ \\
\hline \multirow[t]{3}{*}{ Cinobufagin } & 1 & 5 & $5.91 \pm 0.12$ & $0.5 \pm 0.3$ & $0.5 \pm 0.9$ & $1.8 \pm 0.9$ & $5.2 \pm 1.9$ & $8.4 \pm 2.6$ & $8.3 \pm 3.8$ \\
\hline & 2 & 5 & $5.82 \pm 0.19$ & $0.6 \pm 0.9$ & $0.7 \pm 1.0$ & $2.3 \pm 1.5$ & $4.8 \pm 2.4$ & $6.7 \pm 2.7$ & $8.4 \pm 2.6$ \\
\hline & 4 & 5 & $5.92 \pm 0.30$ & $4.9 \pm 1.4^{* *}$ & * $7.8 \pm 1.0^{* *}$ & $9.5 \pm 1.4^{* *}$ & $16.0 \pm 1.5^{* *}$ & $18.7 \pm 2.2^{* *}$ & $18.6 \pm 2.1^{* *}$ \\
\hline \multirow[t]{3}{*}{ Toad venom } & 2 & 5 & $5.55 \pm 0.35$ & $0.3 \pm 2.1$ & $-2.0 \pm 2.1$ & $1.5 \pm 1.2$ & $2.7 \pm 0.9$ & $2.5 \pm 0.7$ & $0.9 \pm 1.4$ \\
\hline & 4 & 5 & $5.48 \pm 0.19$ & $2.2 \pm 1.5$ & $5.8 \pm 2.2^{* *}$ & $7.0 \pm 2.5$ & $6.3 \pm 2.8$ & $6.7 \pm 3.3$ & $6.9 \pm 3.3$ \\
\hline & 8 & 5 & $5.27 \pm 0.27$ & $6.5 \pm 3.5$ & $9.1 \pm 3.4$ & $7.2 \pm 3.7$ & $7.8 \pm 2.3^{*}$ & $10.2 \pm 1.4^{* *}$ & $13.2 \pm 2.3^{* *}$ \\
\hline \multirow[t]{3}{*}{ Methyldigoxin } & 0.5 & 5 & $5.74 \pm 0.35$ & $-1.3 \pm 1.1$ & $0.8 \pm 0.7$ & $2.1 \pm 1.2$ & $5.0 \pm 2.0$ & $6.6 \pm 2.6$ & $8.3 \pm 2.9$ \\
\hline & 1 & 5 & $5.57 \pm 0.24$ & $-0.8 \pm 1.1$ & $2.5 \pm 0.4$ & $5.3 \pm 0.9^{* *}$ & $8.1 \pm 1.0^{* *}$ & $9.3 \pm 2.0^{*}$ & $11.6 \pm 2.5^{*}$ \\
\hline & 2 & 5 & $5.55 \pm 0.15$ & $1.4 \pm 0.7$ & $3.1 \pm 0.7$ & $5.4 \pm 0.8^{* *}$ & $9.9 \pm 1.1^{* *}$ & $10.6 \pm 1.3^{* *}$ & $12.0 \pm 1.9^{*}$ \\
\hline \multirow[t]{2}{*}{ Digoxin } & 2 & 5 & $6.25 \pm 0.39$ & $-2.1 \pm 1.5$ & $-0.8 \pm 1.4$ & $0.0 \pm 1.4$ & $1.9 \pm 1.2$ & $2.3 \pm 2.1$ & $2.8 \pm 2.3$ \\
\hline & 4 & 5 & $5.39 \pm 0.15$ & $-0.6 \pm 0.4$ & $1.7 \pm 1.5$ & $3.2 \pm 1.8$ & $8.0 \pm 3.0^{*}$ & $12.8 \pm 3.6$ & $14.5 \pm 4.2^{*}$ \\
\hline Digitoxin & 8 & 5 & $6.19 \pm 0.28$ & $0.2 \pm 0.3$ & $-0.4 \pm 1.0$ & $2.7 \pm 1.3$ & $3.1 \pm 1.9$ & $4.4 \pm 2.1$ & $5.3 \pm 2.8$ \\
\hline Digitoxigenin & 16 & 5 & $5.39 \pm 0.13$ & $0.6 \pm 1.3$ & $0.6 \pm 1.7$ & $1.7 \pm 2.3$ & $0.6 \pm 2.1$ & $2.7 \pm 3.3$ & $3.8 \pm 3.8$ \\
\hline \multirow[t]{2}{*}{ Proscillaridin } & 0.5 & 5 & $5.70 \pm 0.32$ & $-0.1 \pm 0.3$ & $1.6 \pm 0.4$ & $2.8 \pm 0.5$ & $6.8 \pm 1.8^{*}$ & $7.4 \pm 2.6$ & $8.0 \pm 2.7$ \\
\hline & 1 & 5 & $5.47 \pm 0.21$ & $0.4 \pm 0.4$ & $3.2 \pm 1.6$ & $5.5 \pm 2.0^{* *}$ & $7.7 \pm 2.3^{*}$ & $8.1 \pm 2.0$ & $6.5 \pm 1.7$ \\
\hline \multirow[t]{2}{*}{ Aminophylline } & 6.25 & 5 & $5.24 \pm 0.14$ & $-2.1 \pm 1.4$ & $-1.0 \pm 0.7$ & $-1.9 \pm 0.8$ & $1.3 \pm 1.2$ & $1.6 \pm 1.4$ & $-0.9 \pm 3.1^{*}$ \\
\hline & 12.5 & 5 & $5.15 \pm 0.30$ & $7.2 \pm 2.7$ & $8.4 \pm 2.5^{*}$ & $7.9 \pm 2.9$ & $8.3 \pm 3.8$ & $11.7 \pm 3.7$ & $12.9 \pm 4.1^{*}$ \\
\hline Control & & 3 & $4.67 \pm 0.33$ & $-1.0 \pm 0.5$ & $-2.4 \pm 1.9$ & $-2.3 \pm 1.5$ & $-0.1 \pm 2.3$ & $0.6 \pm 2.3$ & $0.9 \pm 2.0$ \\
\hline \multirow[t]{3}{*}{ Bufalin } & 0.5 & 3 & $4.52 \pm 0.29$ & $0.7 \pm 0.7$ & $-0.2 \pm 2.7$ & $-0.4 \pm 3.4$ & $1.0 \pm 3.1$ & $1.3 \pm 3.7$ & $1.0 \pm 4.0$ \\
\hline & 1 & 3 & $5.30 \pm 0.40$ & $1.0 \pm 0.5$ & $0.4 \pm 0.4$ & $2.4 \pm 0.7^{*}$ & $4.2 \pm 1.2$ & $9.0 \pm 2.1$ & $8.7 \pm 1.8^{*}$ \\
\hline & 2 & 4 & $5.11 \pm 0.41$ & $2.6 \pm 0.5^{* *}$ & * $3.7 \pm 1.0^{*}$ & $6.6 \pm 2.0^{*}$ & $9.7 \pm 2.6^{*}$ & $9.9 \pm 3.7$ & $8.0 \pm 7.1$ \\
\hline Cinobufagin & 4 & 3 & $4.37 \pm 0.25$ & $2.1 \pm 2.2$ & $5.6 \pm 2.2$ & $7.8 \pm 1.4^{* *}$ & $9.2 \pm 1.1^{*}$ & $8.1 \pm 1.1^{*}$ & $3.7 \pm 2.6$ \\
\hline Resibufogenin & 8 & 3 & $5.15 \pm 0.35$ & $-0.6 \pm 1.2$ & $-1.5 \pm 2.0$ & $-1.5 \pm 2.5$ & $-1.9 \pm 2.4$ & $-0.6 \pm 1.6$ & $1.6 \pm 0.6$ \\
\hline
\end{tabular}

The data are expressed as the mean \pm S.E. N: number of guinea pigs. ${ }^{*}: \mathrm{P}<0.05,{ }^{* *}: \mathrm{P}<0.01$, as compared with the control groups by the $t$-test. 
Table 6 Effects of intraduodenal administration of cinobufagin, bufalin, toad venom and other cardiotonics on heart rate in guinea pigs

\begin{tabular}{|c|c|c|c|c|c|c|c|c|c|}
\hline \multirow{3}{*}{ Drugs } & \multirow{3}{*}{$\begin{array}{c}\text { Dose } \\
(\mathrm{mg} / \mathrm{kg})\end{array}$} & \multirow{3}{*}{$\mathrm{N}$} & \multirow{3}{*}{$\begin{array}{c}\text { Before } \\
\text { (beats } / \mathrm{min} \text { ) }\end{array}$} & \multicolumn{6}{|c|}{$\triangle$ Change $(\%)$} \\
\hline & & & & \multicolumn{6}{|c|}{ Time after administration (min) } \\
\hline & & & & 10 & 20 & 30 & 60 & 90 & 120 \\
\hline Control & & 15 & $244 \pm 5$ & $-1.8 \pm 0.5$ & $-1.2 \pm 0.6$ & $-1.0 \pm 0.7$ & $-1.4 \pm 0.9$ & $-1.6 \pm 1.5$ & $-2.7 \pm 1.4$ \\
\hline \multirow[t]{3}{*}{ Cinobufagin } & 1 & 5 & $253 \pm 6$ & $-0.6 \pm 1.1$ & $-0.4 \pm 1.8$ & $-0.5 \pm 1.7$ & $-1.0 \pm 3.1$ & $-2.8 \pm 3.4$ & $-5.1 \pm 3.2$ \\
\hline & 2 & 5 & $242 \pm 6$ & $-0.7 \pm 0.2^{*}$ & $-1.2 \pm 0.4$ & $-1.3 \pm 0.7$ & $-2.1 \pm 0.9$ & $-3.6 \pm 1.1$ & $-4.5 \pm 1.7$ \\
\hline & 4 & 5 & $242 \pm 11$ & $-0.4 \pm 1.4$ & $-0.2 \pm 1.3$ & $0.3 \pm 1.1$ & $1.0 \pm 1.2$ & $0.3 \pm 1.4$ & $-0.8 \pm 1.5$ \\
\hline \multirow[t]{3}{*}{ Toad venom } & 2 & 5 & $231 \pm 7$ & $-0.2 \pm 0.6$ & $1.5 \pm 1.0^{*}$ & $1.4 \pm 0.9$ & $0.5 \pm 0.8$ & $-2.2 \pm 1.4$ & $-3.6 \pm 3.5$ \\
\hline & 4 & 5 & $242 \pm 4$ & $-1.7 \pm 1.3$ & $-0.2 \pm 1.1$ & $-0.8 \pm 1.0$ & $-2.3 \pm 0.8$ & $-4.3 \pm 0.9$ & $-4.5 \pm 0.8$ \\
\hline & 8 & 5 & $260 \pm 6$ & $-1.4 \pm 0.8$ & $-0.8 \pm 1.1$ & $0.8 \pm 1.6$ & $-0.3 \pm 1.7$ & $-1.6 \pm 1.1$ & $-1.9 \pm 1.0$ \\
\hline \multirow[t]{3}{*}{ Methyldigoxin } & 0.5 & 5 & $242 \pm 6$ & $-2.0 \pm 0.6$ & $-1.3 \pm 0.5$ & $-1.5 \pm 0.5$ & $-1.2 \pm 0.9$ & $-1.9 \pm 1.6$ & $-1.9 \pm 1.7$ \\
\hline & 1 & 5 & $264 \pm 8$ & $-2.1 \pm 0.3$ & $-1.7 \pm 0.6$ & $-1.2 \pm 1.1$ & $-2.1 \pm 1.1$ & $-2.7 \pm 1.2$ & $-3.2 \pm 1.7$ \\
\hline & 2 & 5 & $256 \pm 7$ & $-0.7 \pm 0.5$ & $-0.1 \pm 0.4$ & $-0.7 \pm 0.5$ & $-1.7 \pm 1.1$ & $-2.9 \pm 1.6$ & $-4.0 \pm 1.9$ \\
\hline \multirow[t]{2}{*}{ Digoxin } & 2 & 5 & $213 \pm 9$ & $-2.7 \pm 1.4$ & $-2.3 \pm 0.9$ & $-1.1 \pm 1.3$ & $-1.4 \pm 1.4$ & $-3.7 \pm 1.2$ & $-4.9 \pm 1.9$ \\
\hline & 4 & 5 & $223 \pm 6$ & $-1.5 \pm 0.2$ & $-0.2 \pm 1.4$ & $0.3 \pm 0.8$ & $0.4 \pm 1.5$ & $0.3 \pm 1.8$ & $0.4 \pm 2.2$ \\
\hline Digitoxin & 8 & 5 & $266 \pm 6$ & $-0.5 \pm 0.5$ & $-0.5 \pm 0.8$ & $-0.1 \pm 1.5$ & $-1.0 \pm 1.9$ & $-2.0 \pm 2.1$ & $-3.0 \pm 2.1$ \\
\hline Digitoxigenin & 16 & 5 & $235 \pm 12$ & $-2.1 \pm 1.0$ & $-0.2 \pm 0.9$ & $-0.3 \pm 1.1$ & $-1.6 \pm 1.2$ & $-2.3 \pm 1.1$ & $-4.3 \pm 1.5$ \\
\hline \multirow[t]{2}{*}{ Proscillaridin } & 0.5 & 5 & $228 \pm 8$ & $-1.6 \pm 0.5$ & $-1.3 \pm 1.1$ & $-1.7 \pm 0.7$ & $-0.8 \pm 2.1$ & $0.5 \pm 3.5$ & $-1.3 \pm 2.9$ \\
\hline & 1 & 5 & $247 \pm 5$ & $-0.5 \pm 0.4$ & $0.6 \pm 0.7$ & $1.2 \pm 1.1$ & $1.1 \pm 1.2$ & $-0.8 \pm 2.0$ & $-2.1 \pm 2.3$ \\
\hline \multirow[t]{2}{*}{ Aminophylline } & 6.25 & 5 & $242 \pm 7$ & $2.8 \pm 0.9^{* *}$ & * $3.1 \pm 1.3^{* *}$ & $2.3 \pm 1.1$ & $0.3 \pm 1.1$ & $-2.7 \pm 1.5$ & $-4.7 \pm 1.7$ \\
\hline & 12.5 & 5 & $229 \pm 9$ & $5.8 \pm 2.5^{*}$ & $10.3 \pm 2.5^{* *}$ & $10.4 \pm 2.4^{* *}$ & $8.1 \pm 3.0^{* *}$ & $7.8 \pm 3.4^{*}$ & $6.7 \pm 4.4^{*}$ \\
\hline Control & & 3 & $232 \pm 9$ & $-2.3 \pm 0.8$ & $-2.8 \pm 1.1$ & $-3.1 \pm 1.4$ & $-2.6 \pm 0.7$ & $-3.0 \pm 0.7$ & $-4.0 \pm 0.1$ \\
\hline \multirow[t]{3}{*}{ Bufalin } & 0.5 & 3 & $229 \pm 6$ & $-0.1 \pm 2.0$ & $-0.2 \pm 3.0$ & $-0.4 \pm 3.1$ & $-0.7 \pm 4.7$ & $0.4 \pm 5.5$ & $-0.7 \pm 5.4$ \\
\hline & 1 & 3 & $242 \pm 1$ & $-1.7 \pm 1.2$ & $-2.7 \pm 1.5$ & $-1.5 \pm 2.1$ & $-1.9 \pm 2.3$ & $-4.1 \pm 3.3$ & $-6.3 \pm 1.8$ \\
\hline & 2 & 4 & $225 \pm 6$ & $-3.7 \pm 1.0$ & $-3.5 \pm 1.3$ & $-4.3 \pm 1.3$ & $-6.5 \pm 2.5$ & $-6.2 \pm 1.5$ & Arrhythmia \\
\hline Cinobufagin & 4 & 3 & $235 \pm 1$ & $-2.0 \pm 1.0$ & $-3.1 \pm 1.4$ & $-4.4 \pm 1.5$ & $-3.6 \pm 2.2$ & $-2.5 \pm 3.7$ & $-3.0 \pm 4.9$ \\
\hline Resibufogenin & 8 & 3 & $229 \pm 6$ & $-0.6 \pm 0.5$ & $-1.9 \pm 0.7$ & $-3.1 \pm 0.9$ & $-4.0 \pm 0.7$ & $-5.5 \pm 1.5$ & $-6.7 \pm 1.1$ \\
\hline
\end{tabular}

The data are expressed as the mean \pm S.E. $N$ : number of guinea pigs. ${ }^{*}: \mathrm{P}<0.05,{ }^{* *}: \mathrm{P}<0.01$, as compared with the control groups by the $t$-test.

$\mathrm{mg} / \mathrm{kg}$ より心拍数を増加させ, $12.5 \mathrm{mg} / \mathrm{kg}$ では投与 20 分後より心収縮力も増加させた（表 5,6 ）。 心収縮力増 加作用は CB および BF で投与10分後に有意差が認め られたのに対し, APY で20分後, MDG, PC で30分後, DG では60分後に有意差が認められた（表 5 ）.

\section{考察}

$\mathrm{BF}, \mathrm{CB}$ および数種の強心薬の作用をモルモット心室 筋 $\mathrm{Na}^{+}, \mathrm{K}^{+}$-ATPase 活性，モルモット心室乳頭筋活動 電位および開胸モルモットの心収縮力と心拍数を指標と して静脈内投与および十二指腸内投与で比較した。心室 筋 $\mathrm{Na}^{+}, \mathrm{K}^{+}$-ATPase 活性に対する作用はそれぞれの被 験薬の強心作用発現部位と考えられる酵素に対する直接 作用をあらわし，乳頭筋活動電位に対する作用ではこれ
に組織への取り込みの因子が加わったものを,さらに静 脈内投与ならびに十二指腸内投与による作用では薬物の 吸収, 代謝, 血清タンパク質との結合などが加味された ものをあらわしていると考えられる.

$\mathrm{Na}^{+}, \mathrm{K}^{+}$-ATPase 活性に対する阻害作用強度は, IC 50 で比較すると $\mathrm{BF}>\mathrm{DG}>\mathrm{DT}>\mathrm{TCB}>\mathrm{GBF}>\mathrm{CBF}$ $>\mathrm{CB}>\mathrm{GS}>\mathrm{DTG}>\mathrm{RB}$ の順であった．本実験における CB, GS, DTG の IC50 の相対強度は Shimada 5 7$)$ の報 告に拈けるそれと類似していた。すなわち, bufadienolides のらちでは BF が最も阻害作用が強く, RB は最も阻害作用が弱く, CB はその中間の作用を示した. $\mathrm{DG}$ および DT の阻害作用は BFと $\mathrm{CB}$ の間であり, bufadienolides $の \mathrm{Na}^{+}, \mathrm{K}^{+}$-ATPase 活性阻害作用が cardenolidesのそれに抙色ないことが示された. 一般的 
に $\mathrm{Na}^{+}, \mathrm{K}^{+}$-ATPase 活性阻害作用は強心ステロイドの 強心作用発現機構とされて拈り ${ }^{8.99}, \mathrm{BF} や \mathrm{CB}$ などの bufadienolides の強心作用発現には $\mathrm{Na}^{+}, \mathrm{K}^{+}$-ATPase 活性阻害作用が関与しているものと考学られた.

乳頭筋活動電位に対し，CB，GS，DTGはともに添加 30分後に打いて静止膜電位には影響を与えずに APD50 を著明に短縮させた。APD 50 の短縮強度は $\mathrm{GS}>\mathrm{CB}>\mathrm{DTG} \gg \mathrm{DT}$ の順であり, DTと $\mathrm{CB}, \mathrm{GS}$ の 関係は $\mathrm{Na}^{+}, \mathrm{K}^{+}$-ATPase 活性阻害作用の場合と逆転し ていた. GS は DT に比べ心筋への取り込み速度が速い ことが報告されている10)ことから，この結果はGSの 組織への移行性が DT に勝っていることによるものと 考えられた。 また，本実験結果には薬物の溶解性も関与 しているものと思われた，すなわち，水への溶解性が高 いGS の作用は強く現われ，水に溶解しにくいDT の 作用は発現しにくかったものと考えられた。このよらな ことから，30分の観察時間では，DT の作用がほとんど 検出されなかったのかもしれない.なお，強心ステロイ ドの心筋細胞活動電位に対する作用に関する報告は多 ( $8,11 \sim 13)$ が，強心作用とAPDの相関性については 明確な見解が出されていないのが現状である.Hoffmann and Bigger ${ }^{8)}$ は比較的高頻度の刺激下に批ける APD の 短縮がジギタリスの活動電位に対する典型的作用の一つ であり、これはジギタリスが $\mathrm{Na}^{+}, \mathrm{K}^{+}$-ATPase 活性を 阻害することにより, 細胞内の $\mathrm{Na}^{+}$および $\mathrm{Ca}^{2+}$ 濃度 を高め, その結果 $\mathrm{K}^{+}$の透過性が高まり，外向き電流 が増加することに起因すると述べている.この説が正し いとすると, APD の短縮は細胞内 $\mathrm{Ca}^{2+}$ 濃度の上昇, 即ち強心作用, および $\mathrm{Na}^{+}, \mathrm{K}^{+}$-ATPase 活性阻害作用 を反映していることになる。以上のことから，CB にお いて認められた APD 短縮は, $\mathrm{Na}^{+}, \mathrm{K}^{+}$-ATPase 活性 阻害作用と同様に，CB などの bufadienolides が GS な どの cardenolides と類似の作用を有することを意味す るものと考えられる.

開胸モルモットにおいては静脈内投与および十二指腸 内投与において強心作用が認められ，十二指腸内投与に よる $\mathrm{CB}$ 抽よび数種の強心薬の強心作用強度は $\mathrm{MDG}$, $\mathrm{PC}>\mathrm{BF}>\mathrm{CB}>\mathrm{DG}>$ センソ》DT, DTG, RB の順で あった. DT の作用は投与後 2 時間の観察期間で検出さ れなかった，これは DT の水に対する溶解性が低いた めに吸収が悪く, DT の経口投与後の作用発現までの時 間が長い(8)ことによるものと考学られた。強心作用発現

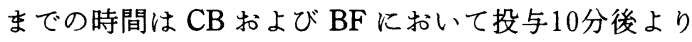
心収縮力增加作用の発現が認められたのに対し, DG,
MDG, PC の作用発現は投与 30 分後以降と遅く, これら の薬物の吸収速度が遅いことあるいは吸收後, 作用発現 までの時間が長いことが示唆された。なお， $\mathrm{BF}^{14)}$ およ び $\mathrm{CB}^{15)}$ の吸収が速やかであることはラットを用いた代 謝実験において報告されている，一方，ホスホジェステ ラーゼ阻害作用を有する APY は陽性変時および陽性変 力作用を有することが知られており ${ }^{16)}$ ，本実験系におい ても䫓著な HR 增加を示し，他の bufadienolides や cardenolides が HR にほとんど影響しなかった点と大 きく異なった。

センソ含有製剤は一般に経口的に用いられるため, 十 二指腸内投与による今回の結果は, $\mathrm{BF} や \mathrm{CB}$ をはじめ とする bufadienolides やそれを成分とするこれらの製 剤の実際的な作用を反映するものと考兄られる. 特に, センソにはアドレナリンが含まれている17)ことから， in vitro あるいは静脈内投与実験ではアドレナリンの強 心作用が加算されてしまら恐れがある.今回の結果から， $\mathrm{CB}$ の経口投与後の強心作用について推測すると，その 強度は MDG に及ばないものの DGよりは強力であり， さらに, 強心作用発現時間については, ヒトに颃いて一 般に作用発現が早いとされる $\mathrm{MDG}^{18)}$ と同等か, それ よりも早期に発現するものと考えられた.

センソ中に含有される bufadienolides の主成分は $\mathrm{BF}$ や $\mathrm{CB}$ の他に $\mathrm{RB}$ が挙げられる. RB は十二指腸内 投与によって強心作用を発現せず, $\mathrm{Na}^{+}, \mathrm{K}^{+}$-ATPase 活性阻害作用も弱かったことより, センソの強心作用に はあまり関与していないるのと考兄られた。一方, BF は十二指腸内投与によって CB の約 $1 / 4$ の用量で同等 の強心作用を発現し, $\mathrm{Na}^{+}, \mathrm{K}^{+}$-ATPase 活性阻害作用 も $\mathrm{CB}$ の約11倍強力であった。

以上の結果から，センソの強心成分の $\mathrm{BF} や \mathrm{CB}$ は その薬理作用に拈いては GSなどの cardenolides と類 似していることが示唆され, 経口投与時においては他の 強心薬に比較して発現が速やかであるといった特徽を有 する薬物であると結論づけられた。

\section{文献}

1）森下信一, 齋藤 隆, 三島泰宏, 水谷 睦, 平井 康晴, 川上萬里: Cinobufagin の一般薬理作用 一Digitoxin との比較一. 日薬理誌 86, 269 292 (1985)

2) 山原條二, 田中慎二, 松田久司, 澤田徳之助, 藤村 一: センソ強心ステロイドの灌流心蔵に対する強心 作用特性と, 実験的虚血性心不全に対する 
cinobufagin の作用. 日薬理誌 88, 413 423 (1986)

3）須賀俊郎：センソ (蟾酥) の化学と薬理. 代謝 $\mathbf{1 0}$, 762 774 (1973)

4）小松曼耆, 岡野定輔 : シリカゲルの溶出乾式カラム クロマトグラフィーによるブホステロイドの分離. 薬誌 87, 712〜718 (1967)

5) Kim, D-H., Akera, T. and Brody, T.M.: Inotropic actions of doxorubicin in isolated guinea pig atria: Evidence for lack of involvement of $\mathrm{Na}^{+}, \mathrm{K}^{+}$. adenosine triphosphatase. J. Pharmacol. Exp. Ther. 214, 368 374 (1980)

6) Lowry, O.H., Rosebrough, N.J., Farr, A.L. and Randall, R.J.: Protein measurement with the Folin phenol reagent. J. Biol. Chem. 193, 265 275 (1951)

7) Shimada, K., Ohishi, K., Fukunaga, H., Ro, J.S. and Nambara, T.: Structure-activity relationship of bufotoxins and related compounds for the inhibition of $\mathrm{Na}^{+}, \mathrm{K}^{+}$-adenosine triphosphatase. J. Pharmacobiodyn. 8, 1054 1059 (1985)

8) Hoffman, B.F. and Bigger, J.T.Jr.: Digitalis and allied cardiac glycosides. In The Pharmacological Basis of Therapeutics, 7th ed., Edited by Gilman, A. G., Goodman, L.S., Rall, T.W. and Murad, F., p. $716 \sim 747$, Macmillan Publishing Co., New York (1985)

9) Akera, T. and Brody, T.M.: The role of $\mathrm{Na}^{+}, \mathrm{K}^{+}$ATPase in the inotropic action of digitalis. Pharmacol. Rev. 29, 187〜220 (1978)

10）田中 護, 藤野澄子 : 強心配糖体の体内分布. 強心 薬の薬理, 高木博司, 粕谷 豊, 監修, p. 23 - 52,
朝倉書店，東京 (1971)

11) Ito, M., Hollander, P.B., Marks, B.H. and Dutta, S.: The effects of six cardiac glycosides on the transmembrane potential and contractile characteristics of the right ventricle of guinea pigs. J. Pharmacol. Exp. Ther. 172, 188 195 (1970)

12) Hoffman, B.F.: Effects of digitalis on electrical activity of cardiac fibers. In Digitalis, Edited by Fisch, C. and Surawicz, B., p. 93 109, Grune and Stratton Inc., New York (1969)

13）大塚正徳：強心配糖体の作用機序.医学のあゆみ 53, $1 \sim 6(1965)$

14）東間章二，平井康晴，杉本智潮，庄司政満，小國 泰弘, 森下信一, 伊藤千尋, 堀江正信 : Bufalin の ラットに拈ける体内動態.薬誌 111, 676～686 (1991)

15) Tōma, S., Morishita, S., Kuronuma, K., Mishima, Y., Hirai, Y. and Kawakami, M.: Metabolism and pharmacokinetics of cinobufagin. Xenobiotica 17, 1195 1202 (1987)

16) Rall, T.W.: Central nervous system stimulants. In The Pharmacological Basis of Therapeutics, 7th ed., Edited by Gilman, A.G., Goodman, L.S., Rall, T.W. and Murad, F., p. $589 \sim 603$, Macmillan Publishing Co., New York (1985)

17）松原利行, 上野美穗, 横田洋一，川筋 透, 斉藤 晴夫 : センソ中 Adrenaline の分解とラット胃底平 滑筋弛緩作用の経時的減弱との相関性. 応用薬理 38, $71 \sim 78$ (1989)

18）水重克文，林 英宰，松尾裕英：心配糖体薬. 現代 医療 18, 732 735 (1986)

Abstract-Effects of bufadienolides and some kinds of cardiotonics on guinea pig hearts. Yasuharu HIRAI*, Shin-ichi MORISHITA*, Chihiro ITO* and Matao SAKANASHI** (*Research Laboratories, Kyushin Pharmaceutical Co., Ltd., 1-31-7 Wada, Suginami-ku, Tokyo 166, Japan, and **Department of Pharmacology, School of Medicine, Faculty of Medicine, University of the Ryukyus, 207 Uehara, Nishihara-cho, Okinawa 903-01, Japan). Folia pharmacol. japon. 100, 127 135 (1992)

Effects of bufadienolides such as bufalin (BF) and cinobufagin (CB), the main components of Senso (Ch'an $\mathrm{Su}$ ), on myocardial $\mathrm{Na}^{+}, \mathrm{K}^{+}$-ATPase activity, the cardiotonic activity in vivo and the action potential of isolated guinea pig papillary muscle cells were compared with those of other cardiotonic drugs. 1) The rank order of potency for inhibition of myocardial $\mathrm{Na}^{+}, \mathrm{K}^{+}$-ATPase activity was BF $>$ digoxin $(\mathrm{DG})>$ digitoxin $(\mathrm{DT})>$ telocinobufagin $>$ gamabufotalin $>$ cinobufotalin $>\mathrm{CB}>$ g-strophanthin (GS) > digitoxigenin (DTG) > resibufogenin (RB) when compared at the $50 \%$ inhibitory concentration. 2) In isolated papillary muscle cells, $\mathrm{CB}$ shortened the action potential duration (APD) dosedependently. The order of potency for shortening of APD was GS $>C B>D T G \gg D T$. 3) In open-chest guinea pigs, intraduodenal administration of $\mathrm{BF}$ or $\mathrm{CB}$ increased the myocardial contractile force $(\mathrm{MCF})$, but did not affect the heart rate. The order of potency for increase in MCF was as follows: methyldigoxin, proscillaridin $>\mathrm{BF}>\mathrm{CB}>\mathrm{DG}>$ Senso $\gg \mathrm{DT}, \mathrm{DTG}, \mathrm{RB}$. These results indicate that $\mathrm{CB}$ has a shortening effect on APD and an inhibitory effect on $\mathrm{Na}^{+}, \mathrm{K}^{+}$-ATPase activity along with its cardiotonic effect, like GS. 